The Canadian Mineralogist

Vol. 39, pp. 103-110 (2001)

\title{
BISMUTOTANTALITE FROM NORTHWESTERN ARGENTINA: DESCRIPTION AND CRYSTAL STRUCTURE
}

\author{
MIGUEL ANGEL GALLISKI ${ }^{\S}$ AND M. FLORENCIA MÁRQUEZ-ZAVALÍA ${ }^{\S}$ \\ IANIGLA, CRICYT (CONICET), Avda A. Ruiz Leal s/n Parque Gral. San Martín, CC330, 5500 Mendoza, Argentina \\ MARK A. COOPER ${ }^{\S}$ PETR ČERNÝ§ ${ }^{\S}$ AND FRANK C. HAWTHORNE ${ }^{\S}$ \\ Department of Geological Sciences, University of Manitoba, Winnipeg, Manitoba R3T 2N2, Canada
}

\begin{abstract}
Bismutotantalite occurs in albite-rich cores of the La Elvirita granitic pegmatites, northwestern Argentina, associated mainly with bismuth, bismuthinite, ferrotapiolite, manganotantalite, microlite, uranmicrolite, bismutomicrolite, hafnian zircon and montebrasite. A fresh, $\mathrm{cm}$-sized crystal, dark grey with a greasy luster and $\mathrm{D}=8.809 \mathrm{~g} / \mathrm{cm}^{3}$, was examined. In reflected light, it is grey with very weak bireflectance; two phases can be distinguished. Electron-microprobe analysis gives the host bismutotantalite [Bi] as $\left(\mathrm{Bi}_{0.98} \mathrm{Sb}_{0.02}\right)\left(\mathrm{Ta}_{0.89} \mathrm{Nb}_{0.11}\right) \mathrm{O}_{4}$; the subsidiary phase [Bi,Sb], $\left(\mathrm{Bi}_{0.68} \mathrm{Sb}_{0.32}\right)\left(\mathrm{Ta}_{0.89} \mathrm{Nb}_{0.11}\right) \mathrm{O}_{4}$, is enriched in $\mathrm{Sb}$. Least-squares refinement of X-ray powder-diffraction data of [Bi] gave $a 4.968(1), b 11.796(3), c 5.646(1) \AA, V=330.85(9) \AA^{3}$. The crystal structures of $[\mathrm{Bi}]$ and $[\mathrm{Bi}, \mathrm{Sb}]$ were refined to $R$ indices of 1.9 and $2.4 \%$, based on 387 and 377 observed $(4 \sigma)$ reflections, respectively, measured with MoKa X-radiation. Both phases are orthorhombic, space group Pcnn, $Z=4$; [Bi] has $a$ 4.9652(4), $b$ $11.7831(16), c 5.6462(5) \AA, V 330.32(6) \AA^{3}$, and [Bi,Sb] has $a 4.9471(4), b 11.7878(7), c 5.6048(3) \AA, V 326.83(4) \AA^{3}$. These results show that the centrosymmetric structure of bismutotantalite can accommodate up to $\sim 40 \% \mathrm{Sb}^{3+}$ substituting for $\mathrm{Bi}^{3+}$ without changing to the $P c 2_{1} n$ structure of stibiotantalite.
\end{abstract}

Keywords: bismutotantalite, crystal-structure refinement, electron-microprobe analysis, granitic pegmatite, La Elvirita, Argentina.

\section{SOMMAIRE}

La bismutotantalite est présente dans le coeur riche en albite des massifs de pegmatite granitique de La Elvirita, dans le nordouest de l'Argentine, en association surtout avec bismuth, bismuthinite, ferrotapiolite, manganotantalite, microlite, uranmicrolite, bismutomicrolite, zircon hafnifère et montebrasite. Nous avons porté notre attention sur un cristal centimétrique non altéré, gris foncé, avec un éclat graisseux et une densité de $8.809 \mathrm{~g} / \mathrm{cm}^{3}$. En lumière réfléchie, la bismutotantalite est grise avec une biréflectance très faible; deux phases distinctes sont présentes. Une analyse à la microsonde électronique de la phase hôte [Bi] a donné $\left(\mathrm{Bi}_{0.98} \mathrm{Sb}_{0.02}\right)\left(\mathrm{Ta}_{0.89} \mathrm{Nb}_{0.11}\right) \mathrm{O}_{4}$; la phase accessoire, que nous appelons [Bi,Sb], est enrichie en antimoine: $\left(\mathrm{Bi}_{0.68} \mathrm{Sb}_{0.32}\right)$ $\left(\mathrm{Ta}_{0.89} \mathrm{Nb}_{0.11}\right) \mathrm{O}_{4}$. Une affinement de données de diffraction $\mathrm{X}$ pour [Bi] par la méthode des poudres a donné $a 4.968(1), b$ 11.796(3), c 5.646(1) $\AA, V 330.85(9) \AA^{3}$. Les structures cristallines de [Bi] et de [Bi,Sb] ont été affinées jusqu'à un résidu $R$ de 1.9 et $2.4 \%$, respectivement, en utilisant 387 et 377 réflexions observées $(4 \sigma)$, mesurées avec rayonnement MoK $\alpha$. Les deux phases sont orthorhombiques, groupe spatial Pcnn, $Z=4$; les paramètres de [Bi] sont $a$ 4.9652(4), $b$ 11.7831(16), $c$ 5.6462(5) $\AA$, $V 330.32(6) \AA^{3}$, tandis que ceux de [Bi,Sb] sont $a 4.9471(4), b 11.7878(7), c 5.6048(3) \AA, V 326.83(4) \AA^{3}$. Ces résultats montrent que la structure centrosymmétrique de la bismutotantalite peut accommoder jusqu'à $\sim 40 \% \mathrm{de} \mathrm{Sb}^{3+}$ en substitution du $\mathrm{Bi}^{3+}$ sans transformation à la structure $P c 21 n$ de la stibiotantalite.

(Traduit par la Rédaction)

Mots-clés: bismutotantalite, affinement de la structure cristalline, analyse à la microsonde électronique, pegmatite granitique, La Elvirita, Argentine.

§E-mail addresses: galliski@lab.cricyt.edu.ar, mzavalia@lab.cricyt.edu.ar, mcooper@ms.umanitoba.ca, p_cerny@umanitoba.ca, frank_hawthorne@umanitoba.ca 


\section{INTRODUCTION}

Bismutotantalite, ideally $\mathrm{BiTaO}_{4}$, is a fairly rare mineral that occurs usually in geochemically highly evolved granitic pegmatites (Foord 1982, Černý \& Ercit 1989). Some of the physical and optical properties and the chemical composition have been reported in earlier studies (Wayland \& Spencer 1929, Hurlbut 1957). The mineral was discovered in a granitic pegmatite at Gamba Hill, Kampala, Uganda (Wayland \& Spencer 1929), where it occurs in crystals of up to several kilograms, associated with quartz, kaolinized K-feldspar and buffcolored mica; tourmaline and traces of cassiterite occur in the same pegmatite. Frenzel (1955) studied bismutotantalite from two localities in Brazil: Acary, Rio Grande do Norte, and Recife, Paraiba. Probably, these two localities are the same as those reported by Bhaskara Rao \& Adusumilli (1966): Acari in Rio Grande do Norte, and Picui and Pedra Lavrada, Paraiba, Brazil. At all these Brazilian localities, bismutotantalite is found

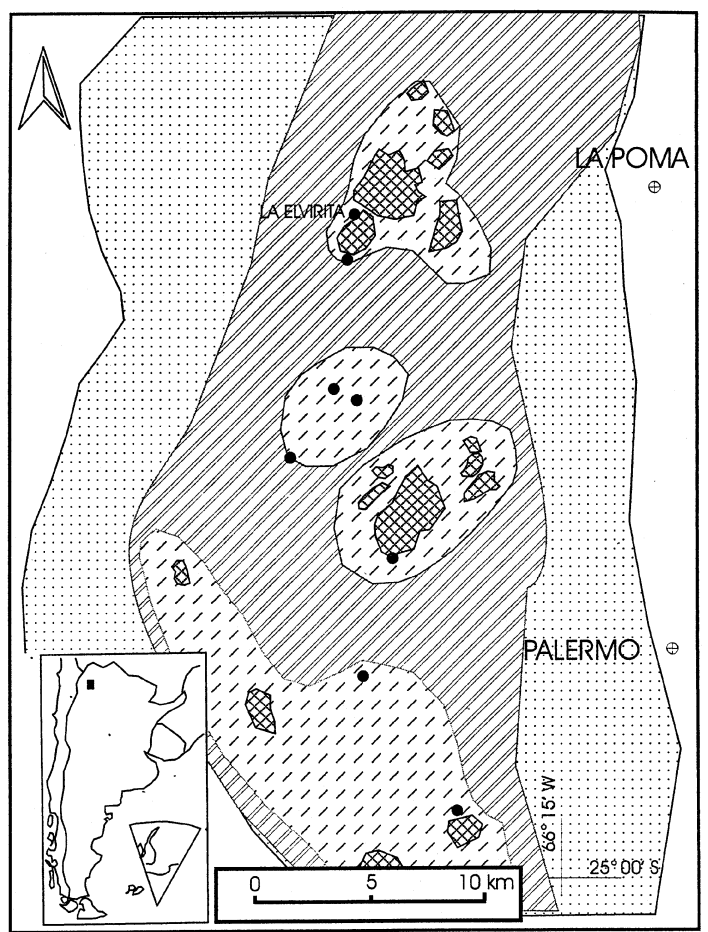

FIG. 1. Geological map of the El Quemado pegmatite field, modified from Galliski (1983a), with the location of La Elvirita pegmatite. Slates and phyllites are dotted, diagonal ruling denotes spotted-slates, phyllites and micaschists, and cordierite-spotted schists and K-feldpar-sillimanitecordierite hornfels are dashed. Rectangular grid represents trondhjemite stocks, and solid circles are rare-element pegmatites. as pebbles in gravel beds. Hurlbut (1957) studied samples of pebbles from Acari and determined the space group of bismutotantalite to be $P c m n$ or $P c 2_{1} n$. Correia Neves et al. (1974) described bismutotantalite occurrences from Mozambique. Von Knorring \& Fadipe (1981) mentioned that bismutotantalite occurs in the Wampewo and Mbele pegmatites, Uganda, where it is commonly altered to bismuthian microlite. Voloshin $e t$ al. (1983) reported the chemical composition of bismutotantalite from the granitic pegmatites of Koktokai, Sincizyan, China. In spite of all this work, the details of the structure of bismutotantalite still remain to be determined.

Ahlfeld \& Angelelli (1948) reported the occurrence of powdery bismutotantalite from the El Quemado granitic pegmatites, northwestern Argentina. During a study of $(\mathrm{Nb}-\mathrm{Ta})$-bearing minerals from pegmatites of the Pampean Ranges, a sample from La Elvirita mine, one of the pegmatites of the El Quemado pegmatite field, was identified as bismutotantalite. Here, we describe the paragenesis, physical and optical properties, chemical composition and crystal structure of bismutotantalite from this locality.

\section{OCCURRENCE}

The La Elvirita mine is located at $24^{\circ} 45^{\prime} 11^{\prime \prime} \mathrm{S}$ and $66^{\circ} 20^{\prime} 44^{\prime \prime}$ W, 4040 m above sea level in Salta Province, northwestern Argentina. It is situated in one of the smaller pegmatites of the El Quemado pegmatite field (Fig. 1), the northernmost rare-element pegmatite field of the Pampean Pegmatite Province. La Elvirita consists of three small pegmatite dikes intruded into the northwestern side of an epizonal trondhjemite stock. The largest dike is $40 \mathrm{~m}$ long and $1.10 \mathrm{~m}$ wide, a tabular body that strikes $\mathrm{N} 20^{\circ} \mathrm{W}$ and dips $45^{\circ} \mathrm{SE}$. The pegmatite consists of border and wall zones and a core (Fig. 2). Quartz, albite and muscovite are the principal minerals of the border zone, and tourmaline is accessory. The wall zone is medium grained and consists of the same minerals plus apatite and manganocolumbite. The core consists of fine-grained albite, subordinate quartz of medium grain-size, and a completely altered pinkish

TABLE 1. REFLECTANCE VALUES (\%) IN AIR FOR BISMUTOTANTALITE

\begin{tabular}{llllll}
\hline Inm & $R_{\max }$ & $R_{\min }$ & $I n m$ & $R_{\max }$ & $R_{\min }$ \\
\hline 400 & 23.0 & 21.8 & 560 & 19.8 & 19.4 \\
420 & 20.5 & 17.8 & 580 & 19.7 & 19.4 \\
440 & 21.3 & 20.8 & 589 & 19.9 & 19.5 \\
460 & 20.9 & 20.2 & 600 & 19.8 & 19.3 \\
470 & 20.2 & 19.5 & 620 & 19.7 & 19.0 \\
480 & 20.6 & 20.3 & 640 & 18.7 & 18.1 \\
500 & 20.6 & 20.4 & 650 & 18.3 & 17.8 \\
520 & 20.8 & 20.1 & 660 & 17.8 & 16.0 \\
540 & 19.9 & 19.6 & 680 & 16.3 & 15.4 \\
546 & 20.3 & 19.8 & 700 & 12.9 & $11.5(1)$ \\
\hline
\end{tabular}


white mineral. In the hanging-wall contact, the core carries montebrasite, hafnian zircon, bismuthinite, tantalite, uranmicrolite and triphylite-like minerals. In samples provided by the owner (collected when the mine was active), bismutotantalite, bismuthinite, bismuth, ferrotapiolite, microlite, uranmicrolite and sphalerite were recognized. Close to the south, in the same pegmatite field, there are some larger dikes of pegmatite with petalite transformed to pseudomorphs of spodumene + quartz, lepidolite, montebrasite, and fairly abundant columbite-group minerals that were mined in 1941-45 and 1957 (Galliski 1983b).

\section{Physical and Optical Properties}

Bismutotantalite occurs in two different samples. One sample consists of a 3-cm-long imperfect crystal with rough brown pyramidal faces. In polished section, this material is grey and consists of bismutotantalite cross-cut by a network of veinlets of tapiolite and minor bismuth. Microlite and bismutomicrolite are common in small grains and microveinlets as an alteration product. The second sample consists of a fresh-looking irregular $3 \times 2 \times 1.5 \mathrm{~cm}$ fragment of a crystal of almost pure bismutotantalite. It is dark grey with a greasy luster (Fig. 3). Two cleavages are clearly visible, corresponding to $\{010\}$ and $\{101\}$ (perfect and fair, respectively). The density was measured with a Berman torsion balance on three different single grains; the average value is $8.809 \mathrm{~g} / \mathrm{cm}^{3}$.

The optical properties and reflectance values were obtained using a Leitz microscope and one of the sili-

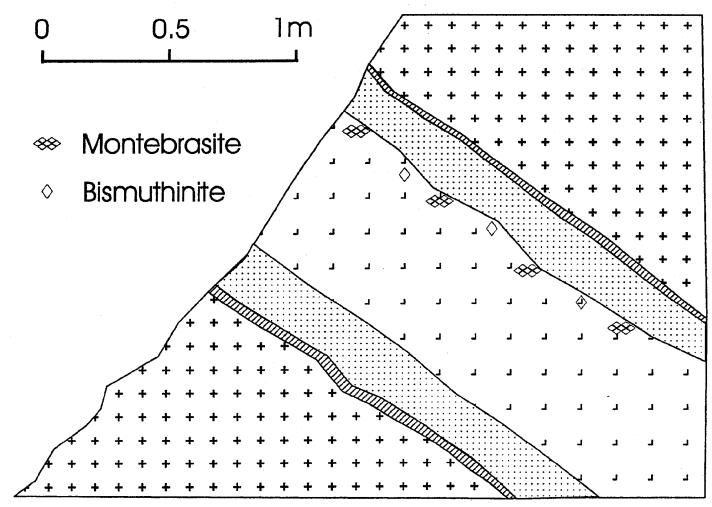

FIG. 2. Sketch of the internal structure of La Elvirita pegmatite. The host rock is trondhjemite, the border zone (with oblique lines) has quartz + albite + muscovite \pm tourmaline, the wall zone (represented by small dots) is composed of quartz + albite + muscovite \pm apatite \pm manganocolumbite. The core has albite, quartz and montebrasite, bismuthinite, and hafnian zircon close to the hanging wall. con samples tested for the paper of Pauly (1986) as a standard. In reflected light, bismutotantalite is grey; its bireflectance is very weak, and pleochroism is not observable. The measured reflectance data are given in Table 1. Anisotropy is negligible in air, but distinct in oil. The colors under crossed nicols are grey to grey with an olive-greenish tint. Despite the weak anisotropy, bismutotantalite seems to shows extinction parallel to the better cleavage, similar to that of columbite-tantalite. Internal reflections are scarce in air, but relatively abundant and darker in oil: yellow, yellowish brown and orange brown. Inclusions of bismuth, bismutomicrolite and Sb-bearing bismutotantalite are common. Bismuth occurs as $20-80 \mu \mathrm{m}$ roundish or elongate inclusions, in some cases accentuating the pattern of cleavage. Bismutomicrolite occurs as $50 \mu \mathrm{m}$ irregular grains. Antimony-bearing bismutotantalite forms roundish to elongate $(<2 \mathrm{~mm})$ patches, which commonly contain small and irregular grains of bismuth (Fig. 4).

\section{Chemical Composition}

Electron-microprobe analysis of bismutotantalite was done in wavelength-dispersion mode on a Cameca SX-50 instrument with a beam diameter of 1-2 $\mu \mathrm{m}$, an acceleration potential of $15 \mathrm{kV}$, and a sample current of $20 \mathrm{nA}$ measured on a Faraday cup. Counting times of $20 \mathrm{~s}$ were used for $\mathrm{Fe}, \mathrm{Mn}, \mathrm{Sn}, \mathrm{Ti}, \mathrm{Nb}$ and $\mathrm{Ta}$; for $\mathrm{Mg}$, $\mathrm{Ca}, \mathrm{Sb}, \mathrm{As}, \mathrm{Bi}, \mathrm{Sc}, \mathrm{Zr}, \mathrm{Pb}$ and $\mathrm{U}, 40 \mathrm{nA}$ and $50 \mathrm{~s}$ were used. The following standards were used: manganotantalite $(\mathrm{Ta} M \alpha), \mathrm{FeNb}_{2} \mathrm{O}_{6}(\mathrm{Fe} K \alpha), \mathrm{MnNb}_{2} \mathrm{O}_{6}(\mathrm{Nb} L \alpha$, $\mathrm{Mn} K \alpha), \mathrm{SnO}_{2}(\mathrm{Sn} L \alpha)$, rutile $(\mathrm{Ti} K \alpha), \mathrm{ZrO}_{2}(\mathrm{Zr} L \alpha)$, $\mathrm{NaScSi}_{2} \mathrm{O}_{6}(\mathrm{Sc} K \alpha)$, YAG $(\mathrm{Y} L \alpha)$, gahnite $(\mathrm{Zn} K \alpha)$, $\mathrm{MgNb}_{2} \mathrm{O}_{6}(\mathrm{Mg} K \alpha), \mathrm{BiTaO}_{4}(\mathrm{Bi} M \alpha), \mathrm{CaWO}_{4}(\mathrm{WM} \beta)$, mimetite (As $L \alpha, \mathrm{Pb} M \alpha), \mathrm{CaNb}_{2} \mathrm{O}_{6}(\mathrm{Ca} K \alpha)$, stibiotantalite $(\mathrm{Sb} L \alpha), \mathrm{ThO}_{2}$ glass $(\mathrm{Th} M \alpha)$ and $\mathrm{UO}_{2}(\mathrm{U} M \alpha)$. Data were reduced using the PAP routine of Pouchou \& Pichoir (1984,1985).

The chemical compositions of the La Elvirita bismutotantalite fall into two groups, representing the host near-end-member bismutotantalite [Bi], and a minor antimony-bearing bismutotantalite phase [Bi,Sb] (Table 2, Fig. 5). The [Bi] phase has a chemical composition close to that of end-member bismutotantalite, with only $3.3 \% \mathrm{Nb}_{2} \mathrm{O}_{5}$, less than $1 \% \mathrm{Sb}_{2} \mathrm{O}_{3}$, and local traces of W, Ti, Th, U, Sc, Mg, Ca, Mn, Fe and Pb. The antimony-bearing bismutotantalite [ $\mathrm{Bi}, \mathrm{Sb}]$ has a slightly higher content of $\mathrm{Ta}_{2} \mathrm{O}_{5}$ (Table 2) and, on average, $11.15 \% \mathrm{Sb}_{2} \mathrm{O}_{3}$. Comparison of chemical compositions with those given in Černý \& Ercit (1989, Fig. 12) shows that the main phase is one of the most Ta- and Bi-rich members of the stibiotantalite group known to date. The average composition of the [Bi] phase is $\left(\mathrm{Bi}_{0.98} \mathrm{Sb}_{0.02}\right)$ $\left(\mathrm{Ta}_{0.89} \mathrm{Nb}_{0.11}\right) \mathrm{O}_{4}$, and the [Bi,Sb] phase averages $\left(\mathrm{Bi}_{0.68} \mathrm{Sb}_{0.32}\right)\left(\mathrm{Ta}_{0.89} \mathrm{Nb}_{0.11}\right) \mathrm{O}_{4}$. The similar $\mathrm{Ta}: \mathrm{Nb}$ ratio in the two phases and the textural relation with bismuth (Fig. 4) suggest that the [Bi,Sb] phase formed by local 


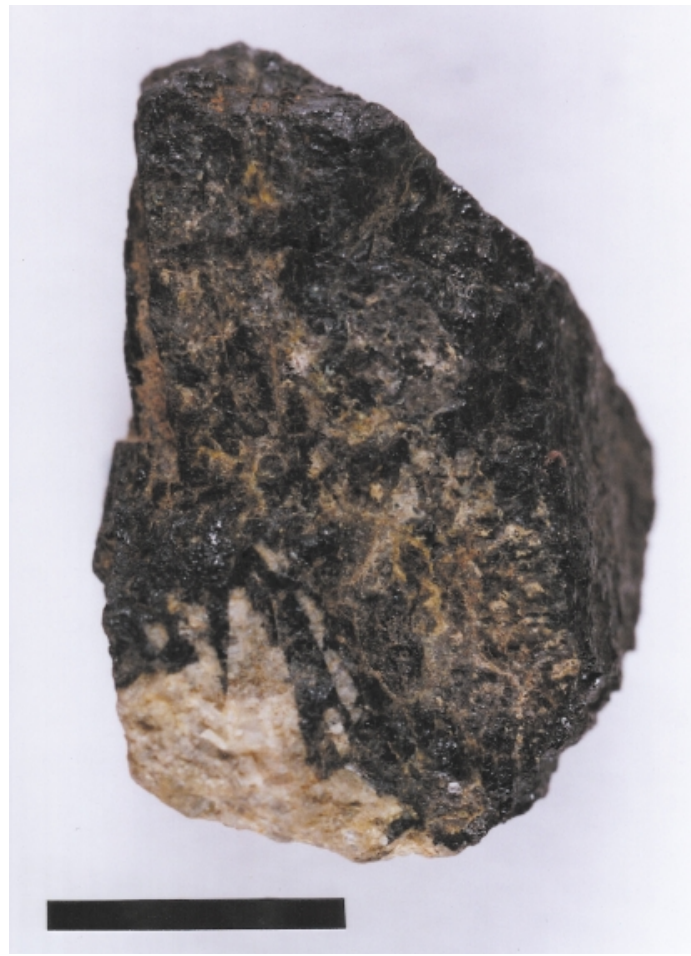

FIG. 3. The sample of bismutotantalite selected for study. The white tabular crystals on the left are albite. Scale bar: $1 \mathrm{~cm}$. replacement of the main phase by a late $\mathrm{Sb}$-rich solution.

\section{X-Ray Powder-Diffraction Data}

X-ray powder-diffraction data were obtained for the [Bi] phase with a Philips 1710 automated powder diffractometer using $\mathrm{Cu} K \alpha \mathrm{X}$-radiation. The data were collected from 5 to $90^{\circ} 2 \theta$ at $0.6^{\circ}$ per minute. Silicon ( $\mathrm{Si}$ batch 649 b NBS, $a=5.430825 \AA$ ) was used as an internal standard, and intensities were measured at peak maxima. The cell parameters were refined with the CELREF program (Appleman \& Evans 1973): $a$ 4.968(1), b 11.796(3), c 5.646(1) ̊, V 330.85(9) $\AA^{3}$. Table 3 gives the $\mathrm{X}$-ray powder-diffraction pattern.

\section{Space Group of Bismutotantalite}

Hurlbut (1957) showed that the cell dimensions of bismutotantalite from Uganda and Brazil are very simi$\operatorname{lar}(a \approx 4.9, b \approx 11.8, c \approx 5.6 \AA)$. Reflection absences on Weissenberg photographs of Brazilian bismutotantalite led Hurlbut (1957) to suggest the space groups $P c m n$ and $P c 2{ }_{1} n$, and Pcmn was assigned because the crystals did not show any pyroelectric or piezoelectric effect. Earlier work on the related phase, stibiotantalite (Penfield \& Ford 1906), showed a strong pyroelectric effect, consistent with the polar space-group $P c 2_{1} n$. More recently, the crystal structure of $\alpha-\mathrm{BiNbO}_{4}$ was

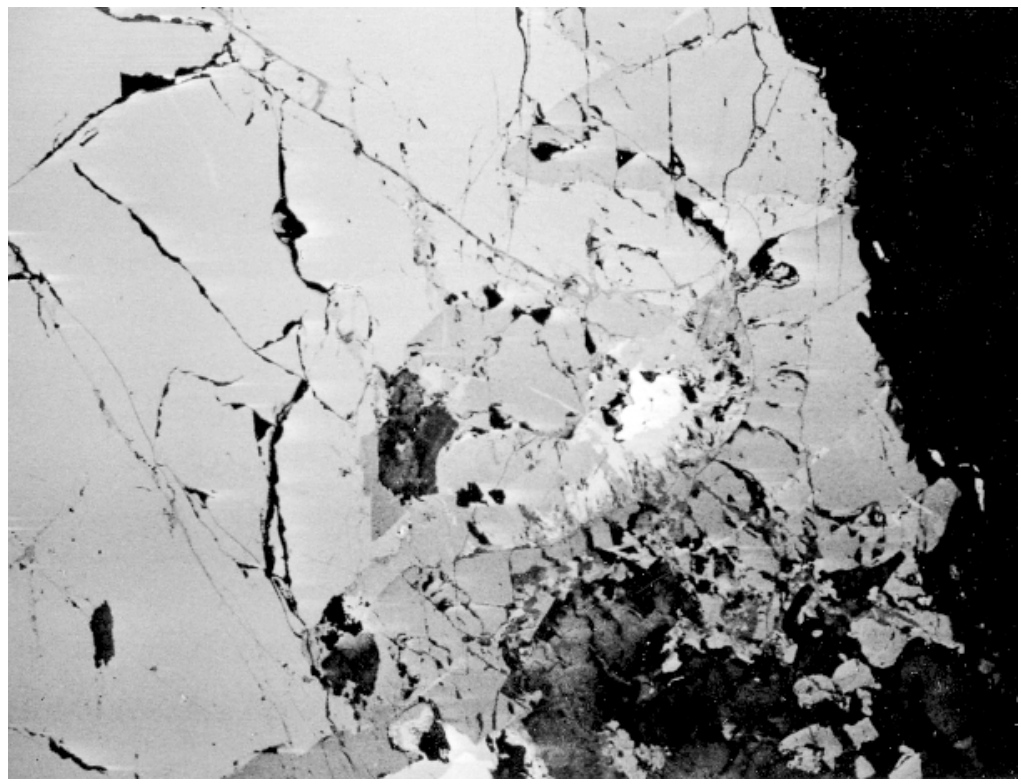

FIG. 4. Back-scattered electron image of bismutotantalite - stibian bismutotantalite; greyish white: native bismuth; pale grey: bismutotantalite; medium grey: stibian bismutotantalite; dark grey: microlite-bismutotantalite. Width of field of view: $1.1 \mathrm{~mm}$. 
$\mathrm{BiNbO}_{4}$

$\mathrm{BiTaO}_{4}$

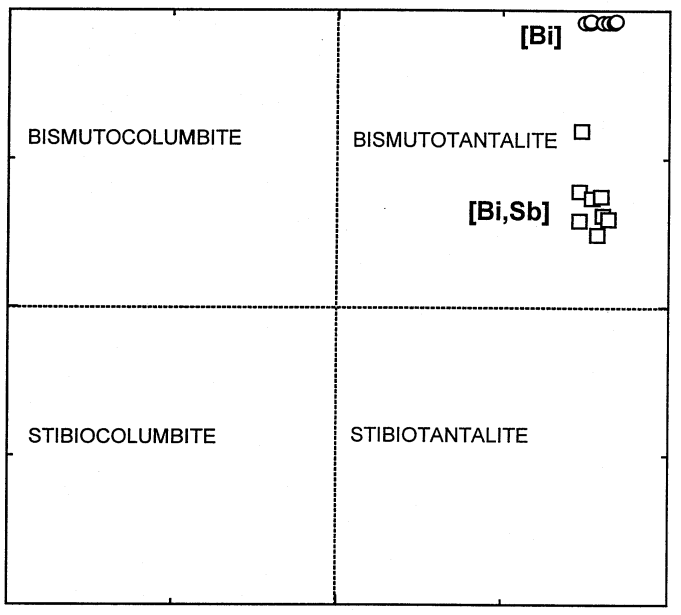

$\mathrm{SbNbO}_{4}$

$\mathrm{SbTaO}_{4}$

FIG. 5. Chemical composition of the two phases of La Elvirita bismutotantalite, plotted in the stibiotantalite-group quadrilateral.

TABLE 2. CHEMICAL COMPOSITION* (wt. \%) AND UNIT FORMULAE (apfu) ${ }^{\star *}$ OF BISMUTOTANTALITE

\begin{tabular}{|c|c|c|c|c|c|c|}
\hline & \multicolumn{3}{|c|}{ MAIN PHASE [Bi] $(\mathrm{N}=9)$} & \multicolumn{3}{|c|}{ MINOR PHASE $[\mathrm{Bi}, \mathrm{Sb}](\mathrm{N}=8)$} \\
\hline & Range & Mean & $\sigma$ & Range & Mean & $\sigma$ \\
\hline $\mathrm{WO}_{3}$ & $0.00-0.58$ & 0.09 & 0.19 & $0.00-0.34$ & 0.09 & 0.12 \\
\hline $\mathrm{Nb}_{2} \mathrm{O}_{5}$ & $2.40-5.03$ & 3.24 & 0.83 & $2.49-4.26$ & 3.50 & 0.69 \\
\hline $\mathrm{Ta}_{2} \mathrm{O}_{5}$ & $41.64-45.19$ & 44.33 & 1.16 & $46.09-48.57$ & 47.05 & 0.84 \\
\hline $\mathrm{TiO}_{2}$ & $0.00-0.17$ & 0.03 & 0.06 & $0.00-0.05$ & 0.01 & 0.02 \\
\hline $\mathrm{ThO}_{2}$ & $0.00-0.13$ & 0.03 & 0.04 & $0.00-0.03$ & 0.01 & 0.01 \\
\hline $\mathrm{UO}_{2}$ & $0.00-0.10$ & 0.03 & 0.03 & $0.00-0.13$ & 0.02 & 0.05 \\
\hline $\mathrm{Sb}_{2} \mathrm{O}_{3}$ & $0.59-0.70$ & 0.63 & 0.03 & $6.76-13.14$ & 11.15 & 1.95 \\
\hline $\mathrm{Bi}_{2} \mathrm{O}_{3}$ & $50.49-52.24$ & 51.30 & 0.67 & $34.79-42.33$ & 37.63 & 2.42 \\
\hline $\mathrm{MnO}$ & $0.00-0.09$ & 0.03 & 0.04 & $0.00-0.02$ & 0.00 & 0.01 \\
\hline $\mathrm{FeO}$ & $0.00-0.08$ & 0.03 & 0.03 & $0.00-0.08$ & 0.02 & 0.03 \\
\hline $\mathrm{PbO}$ & $0.00-0.26$ & 0.06 & 0.10 & $0.00-0.24$ & 0.05 & 0.09 \\
\hline Total & $98.80-101.08$ & 99.84 & 0.79 & $98.61-100.94$ & 99.54 & 0.70 \\
\hline w & $0.000-0.011$ & 0.002 & 0.004 & $0.000-0.006$ & 0.001 & 0.002 \\
\hline $\mathrm{Nb}$ & $0.081-0.165$ & 0.108 & 0.027 & $0.079-0.132$ & 0.110 & 0.020 \\
\hline $\mathrm{Ta}$ & $0.820-0.920$ & 0.889 & 0.031 & $0.864-0.927$ & 0.890 & 0.024 \\
\hline $\mathrm{Ti}$ & $0.000-0.009$ & 0.002 & 0.003 & $0.000-0.003$ & 0.001 & 0.001 \\
\hline $\mathrm{Zr}$ & $0.000-0.000$ & 0.000 & 0.000 & $0.000-0.000$ & 0.000 & 0.000 \\
\hline Th & $0.000-0.002$ & 0.000 & 0.001 & $0.000-0.000$ & 0.000 & 0.000 \\
\hline$U$ & $0.000-0.001$ & 0.000 & 0.000 & $0.000-0.002$ & 0.000 & 0.001 \\
\hline $\mathrm{Sb}$ & $0.018-0.021$ & 0.019 & 0.001 & $0.200-0.374$ & 0.319 & 0.053 \\
\hline $\mathrm{Bi}$ & $0.972-0.978$ & 0.975 & 0.002 & $0.620-0.783$ & 0.675 & 0.051 \\
\hline $\mathrm{Mn}$ & $0.000-0.006$ & 0.002 & 0.002 & $0.000-0.001$ & 0.000 & 0.000 \\
\hline $\mathrm{Fe}_{2}$ & $0.000-0.005$ & 0.002 & 0.002 & $0.000-0.005$ & 0.001 & 0.002 \\
\hline $\mathrm{Pb}$ & $0.000-0.005$ & 0.001 & 0.002 & $0.000-0.004$ & 0.001 & 0.001 \\
\hline Total & $1.999-2.005$ & 2.003 & & $1.994-2.004$ & 1.999 & \\
\hline
\end{tabular}

* Sn, Sc, Mg, Ca, Zn, Zr, As, Y not detected

** calculated on the basis of four $\mathrm{O}$ atoms; reported in Pnna [三Pcnn] (Subramanian \& Calabrese 1993). The space groups $P c 2_{1} n$ and $P c m n$ can be differentiated only on the basis of dissimilarity between Friedel pairs of reflections. However, $\left(P c 2{ }_{1} n, P c m n\right)$ and the uniquely determined $P$ cnn can be distinguished on the basis of systematic absences of reflections.

To help resolve the correct space-group for bismutotantalite, we extracted single crystals from the $[\mathrm{Bi}]$ and $[\mathrm{Bi}, \mathrm{Sb}]$ phases and collected long-exposure precession photographs down the $11 \AA$ axis. For both crystals, all observed $(h 0 l)$ reflections were found to be consistent with the condition $h+l=2 n$, in accord with Pcnn symmetry.

\begin{tabular}{rlllllrllllll}
\multicolumn{1}{c}{ TABLE 3. X-RAY POWDER-DIFFRACTION DATA FOR BISMUTOTANTALITE } \\
\hline \multicolumn{1}{r}{$l$} & $d_{\text {obs }}(\AA)$ & $d_{\text {calc }}(\AA)$ & $h$ & $k$ & $l$ & $l$ & $d_{\text {obs }}(\AA)$ & $d_{\text {calc }}(\AA)$ & $h$ & $k$ & $l$ \\
\hline 2 & 5.905 & 5.898 & 0 & 2 & 0 & 3 & 1.967 & 1.966 & 2 & 3 & 1 \\
4 & 4.584 & 4.578 & 1 & 1 & 0 & 15 & 1.899 & 1.900 & 2 & 4 & 0 \\
5 & 3.731 & 3.730 & 1 & 0 & 1 & 8 & 1.864 & 1.865 & 2 & 0 & 2 \\
25 & 3.556 & 3.556 & 1 & 1 & 1 & 10 & 1.841 & 1.842 & 2 & 1 & 2 \\
100 & 3.151 & 3.152 & 1 & 2 & 1 & 4 & 1.809 & 1.810 & 0 & 5 & 2 \\
5 & 3.082 & 3.083 & 1 & 3 & 0 & 7 & 1.778 & 1.778 & 2 & 2 & 2 \\
40 & 2.951 & 2.949 & 0 & 4 & 0 & 9 & 1.760 & 1.760 & 1 & 0 & 3 \\
12 & 2.823 & 2.823 & 0 & 0 & 2 & 20 & 1.740 & 1.739 & 1 & 6 & 1 \\
10 & 2.746 & 2.745 & 0 & 1 & 2 & 8 & 1.685 & 1.685 & 2 & 3 & 2 \\
9 & 2.705 & 2.706 & 1 & 3 & 1 & 4 & 1.612 & 1.613 & 0 & 6 & 2 \\
9 & 2.547 & 2.546 & 0 & 2 & 2 & 4 & 1.608 & 1.606 & 1 & 3 & 3 \\
15 & 2.483 & 2.484 & 2 & 0 & 0 & 8 & 1.575 & 1.576 & 2 & 4 & 2 \\
1 & 2.398 & 2.403 & 1 & 1 & 2 & 10 & 1.534 & 1.534 & 3 & 2 & 1 \\
5 & 2.311 & 2.313 & 1 & 4 & 1 & 8 & 1.512 & 1.511 & 1 & 4 & 3 \\
4 & 2.294 & 2.293 & 0 & 3 & 2 & 3 & 1.488 & 1.488 & 2 & 1 & 3 \\
4 & 2.289 & 2.289 & 2 & 2 & 0 & 6 & 1.476 & 1.474 & 0 & 8 & 0 \\
2 & 2.266 & 2.266 & 1 & 2 & 2 & 6 & 1.473 & 1.473 & 3 & 3 & 1 \\
2 & 2.232 & 2.233 & 2 & 1 & 1 & 3 & 1.463 & 1.463 & 2 & 5 & 2 \\
2 & 2.083 & 2.082 & 1 & 3 & 2 & 3 & 1.446 & 1.447 & 0 & 7 & 2 \\
10 & 2.039 & 2.039 & 0 & 4 & 2 & 2 & 1.420 & 1.418 & 3 & 1 & 2 \\
5 & 1.994 & 1.994 & 1 & 5 & 1 & 3 & 1.411 & 1.411 & 1 & 5 & 3 \\
\hline & & & & & & & & &
\end{tabular}

TABLE 4. RESULTS OF CRYSTAL-STRUCTURE REFINEMENT FOR BISMUTOTANTALITE

\begin{tabular}{lcc}
\hline & {$[\mathrm{Bi}]$ phase } & {$[\mathrm{Bi}, \mathrm{Sb}]$ phase } \\
\hline$a(\AA)$ & $4.9652(4)$ & $4.9471(4)$ \\
$b$ & $11.7831(6)$ & $11.7878(7)$ \\
$c$ & $5.6462(5)$ & $5.6048(3)$ \\
$V\left(\AA^{3}\right)$ & $330.32(6)$ & $326.83(4)$ \\
Space group & $P c n n$ & $P c n n$ \\
$Z$ & 4 & 4 \\
Crystal size $(\mathrm{mm})$ & $0.14 \times 0.10 \times 0.15$ & $0.10 \times 0.08 \times 0.04$ \\
Radiation & MoKa/Graphite & MoKa/Graphite \\
No. of $F_{0}^{2}$ & 450 & 434 \\
$R_{1}\left(\left|F_{\mathrm{o}}\right|>4 \sigma\right) \%$ & 1.9 & 2.4 \\
$w R_{2}\left(F_{0}^{2}\right) \%$ & 4.1 & 6.1 \\
Site occupancies & & \\
$B i$ site & $0.96(2) \mathrm{Bi}+0.04(2) \mathrm{Sb}$ & $0.62(2) \mathrm{Bi}+0.38(2) \mathrm{Sb}$ \\
$T$ a site & $0.84(2) \mathrm{Ta}+0.16(2) \mathrm{Nb}$ & $0.92(2) \mathrm{Ta}+0.08(2) \mathrm{Nb}$ \\
\hline & \multicolumn{2}{l}{}
\end{tabular}


TABLE 5. ATOM COORDINATES AND DISPLACEMENT PARAMETERS $\left(U=U \times 10^{4}\right)$ FOR BISMUTOTANTALITE

\begin{tabular}{|c|c|c|c|c|c|c|c|c|c|c|}
\hline Site & $x$ & $y$ & $z$ & $U_{11}$ & $U_{22}$ & $U_{33}$ & $U_{23}$ & $U_{13}$ & $U_{12}$ & $U_{\text {eq }}$ \\
\hline \multicolumn{11}{|c|}{ [Bi] phase } \\
\hline$B i$ & $0.22147(6)$ & $1 / 2$ & $1 / 4$ & $0.0083(2)$ & $0.0112(2)$ & $0.0108(2)$ & $0.0011(1)$ & 0 & 0 & $0.0101(1)$ \\
\hline $\mathrm{Ta}$ & $1 / 4$ & $3 / 4$ & $0.64078(5)$ & $0.0066(2)$ & $0.0068(2)$ & $0.0069(2)$ & 0 & 0 & $-0.0001(1)$ & $0.0068(2)$ \\
\hline$O(1)$ & $0.49543(85)$ & $0.69489(41)$ & $0.36094(57)$ & $0.0136(17)$ & $0.0138(21)$ & $0.0142(16)$ & $-0.0007(15)$ & $0.0040(13)$ & $-0.0006(20)$ & $0.0139(9)$ \\
\hline $\mathrm{O}(2)$ & $0.08657(78)$ & $0.59742(36)$ & $0.58723(52)$ & $0.0143(18)$ & $0.0082(18)$ & $0.0105(12)$ & $0.0005(15)$ & $0.0035(14)$ & $-0.0040(17)$ & $0.0110(9)$ \\
\hline \multicolumn{11}{|c|}{$[\mathrm{Bi}, \mathrm{Sb}]$ phase } \\
\hline$B i$ & $0.21854(11)$ & $1 / 2$ & $1 / 4$ & $0.0079(3)$ & $0.0078(3)$ & $0.0096(3)$ & $0.0016(1)$ & 0 & 0 & $0.0084(2)$ \\
\hline $\mathrm{Ta}$ & $1 / 4$ & $3 / 4$ & $0.63557(6)$ & $0.0016(3)$ & $0.0043(3)$ & $0.0048(3)$ & 0 & 0 & $0.0002(1)$ & $0.0035(2)$ \\
\hline$O(1)$ & $0.49292(124)$ & $0.69680(41)$ & $0.35839(77)$ & $0.0093(30)$ & $0.0091(25)$ & $0.0110(22)$ & $0.0006(17)$ & $0.0044(19)$ & $-0.0050(24)$ & $0.0098(13)$ \\
\hline $\mathrm{O}(2)$ & $0.08608(116)$ & $0.59692(39)$ & $0.58587(78)$ & $0.0070(29)$ & $0.0075(21)$ & $0.0099(18)$ & $-0.0015(19)$ & $0.0043(23)$ & $-0.0010(23)$ & $0.0081(12)$ \\
\hline
\end{tabular}

TABLE 6. SELECTED INTERATOMIC DISTANCES (Å) AND ANGLES $\left({ }^{\circ}\right)$ FOR BISMUTOTANTALITE

\begin{tabular}{|c|c|c|c|c|c|c|c|}
\hline \multirow[b]{2}{*}{$\mathrm{Bi}-\mathrm{O}(1), \mathrm{b}$} & \multirow{2}{*}{$\begin{array}{l}\text { [Bi] phase } \\
2.742(5)\end{array}$} & \multicolumn{2}{|c|}{ [Bi,Sb] phase } & \multirow[b]{2}{*}{$T a-O(1) e, f$} & \multirow{2}{*}{$\frac{\text { [Bi] phase }}{1.888(4)}$} & \multicolumn{2}{|c|}{$[\mathrm{Bi}, \mathrm{Sb}]$ phase } \\
\hline & & $2.756(5)$ & $x 2$ & & & $1.890(5)$ & $x 2$ \\
\hline $\mathrm{Bi}-\mathrm{O}(2) \mathrm{a}, \mathrm{C}$ & $2.122(4)$ & $2.103(5)$ & $x 2$ & $\mathrm{Ta}-\mathrm{O}(1), \mathrm{d}$ & $2.098(4)$ & $2.062(5)$ & $x 2$ \\
\hline $\mathrm{Bi}-\mathrm{O}(2), \mathrm{b}$ & $2.322(3)$ & $\underline{2.297(5)}$ & $x 2$ & $T a-O(2), d$ & $1.996(4)$ & $1.998(5)$ & $x 2$ \\
\hline$<B i-O>$ & 2.395 & 2.385 & & $<$ Ta-O $>$ & 1.994 & 1.983 & \\
\hline$O(2)-B i-O(1)$ & $62.7(2)$ & $62.7(2)$ & $x 2$ & $\mathrm{O}(2)-\mathrm{Ta}-\mathrm{O}(1)$ & $81.0(2)$ & $81.8(2)$ & $x 2$ \\
\hline $\mathrm{O}(2)-\mathrm{Bi}-\mathrm{O}(1) \mathrm{b}$ & $138.1(2)$ & $137.7(2)$ & $x 2$ & $\mathrm{O}(2)-\mathrm{Ta}-\mathrm{O}(1) \mathrm{d}$ & $85.9(2)$ & $86.2(2)$ & $x 2$ \\
\hline $\mathrm{O}(2)-\mathrm{Bi}-\mathrm{O}(2) \mathrm{a}$ & $72.8(2)$ & $73.0(2)$ & $x 2$ & $\mathrm{O}(2)-\mathrm{Ta}-\mathrm{O}(1) \mathrm{e}$ & $93.6(2)$ & $93.8(2)$ & $x 2$ \\
\hline $\mathrm{O}(2)-\mathrm{Bi}-\mathrm{O}(2) \mathrm{c}$ & $83.1(2)$ & $83.3(2)$ & $x 2$ & $O(2)-T a-O(1) f$ & $97.9(2)$ & $96.8(2)$ & $x 2$ \\
\hline $\mathrm{O}(1)-\mathrm{Bi}-\mathrm{O}(2) \mathrm{c}$ & $90.2(2)$ & $89.5(2)$ & $x 2$ & $\mathrm{O}(1)-\mathrm{Ta}-\mathrm{O}(1) \mathrm{e}$ & $90.0(2)$ & $90.3(2)$ & $x 2$ \\
\hline$O(1)-B i-O(1) a$ & $120.5(2)$ & $121.0(2)$ & & $\mathrm{O}(1)-\mathrm{Ta}-\mathrm{O}(1) \mathrm{d}$ & $82.3(2)$ & $82.2(2)$ & \\
\hline$O(2) a-B i-O(2) c$ & $87.7(2)$ & $88.4(2)$ & & $\mathrm{O}(1) \mathrm{e}-\mathrm{Ta}-\mathrm{O}(1) \mathrm{f}$ & $97.6(2)$ & $97.3(2)$ & \\
\hline
\end{tabular}

a: $-x,-y+1,-z+1 ;$ b: $x, y+1,-z+1 / 2 ;$ c: $-x, y, z-1 / 2 ; d:-x+1 / 2,-y+11 / 2, z ;$ e: $-x+1, y, z+1 / 2$; f: $x-1 / 2, y+1 \frac{1}{2}, z+1 / 2$

\section{Crystal Structure}

For the same two crystals, [Bi] and [Bi,Sb], used for precession photography, single-crystal intensity data were collected $\left(4 \rightarrow 60^{\circ} 2 \theta ; \overline{2} \leq h \leq 7, \overline{1} \overline{6} \leq k \leq 2, \overline{7} \leq l\right.$ $\leq 7)$ using a Siemens $P 4$ instrument. Data were corrected for absorption using a thin-plate $\{[\mathrm{Bi}]=(010)$; $[\mathrm{Bi}, \mathrm{Sb}]=(340)\}$ empirical absorption correction. Systematic absences are consistent with the space group $P c n n$, and the structures were refined using the transformed parameters for $\alpha-\mathrm{BiNbO}_{4}$ (Subramanian \& Calabrese 1993). Ionized scattering factors were used at all sites. The scattering at the $B i$ and $T a$ sites was modeled by refining $[\mathrm{Bi}, \mathrm{Sb}]$ and $[\mathrm{Ta}, \mathrm{Nb}]$ coupled occupancies, respectively. The site populations (Table 4) fall within the range of compositions for each phase as determined by electron-microprobe analysis (Table 2 ). We can simplify the formulae for these two crystals: $[\mathrm{Bi}]=$ $\mathrm{Bi}\left(\mathrm{Ta}_{0.8} \mathrm{Nb}_{0.2}\right) \mathrm{O}_{4}$ and $[\mathrm{Bi}, \mathrm{Sb}]=\left(\mathrm{Bi}_{0.6} \mathrm{Sb}_{0.4}\right)\left(\mathrm{Ta}_{0.9} \mathrm{Nb}_{0.1}\right)$ $\mathrm{O}_{4}$. Atom coordinates and displacement factors are listed in Table 5, selected interatomic distances and angles are given in Table 6. Structure factors may be obtained from The Depository of Unpublished Data, CISTI, National Research Council, Ottawa, Ontario K1A 0S2, Canada. For the two refinements, individual bond-lengths are within $0.036 \AA$, average bond-lengths, within $0.011 \AA$, and polyhedron angles, within $1.1 \%$. Galy et al. (1975) gave a slightly smaller radius for $\mathrm{Sb}^{3+}$ relative to that for $\mathrm{Bi}^{3+}$, in agreement with the slightly smaller $\langle\mathrm{Bi}-\mathrm{O}\rangle$ distance observed for the $[\mathrm{Bi}, \mathrm{Sb}]$ phase. The cell volume for the $[\mathrm{Bi}, \mathrm{Sb}]$ phase $\left(326.8 \AA^{3}\right)$ is also slightly smaller than that of the $[\mathrm{Bi}]$ phase $\left(330.3 \AA^{3}\right)$.

\section{Crystal Chemistry of the Stibiotantalite Group}

Bismutotantalite $\left(\mathrm{BiTaO}_{4}\right)$ and the low-temperature $\alpha$-form of $\mathrm{BiNbO}_{4}$ have space-group symmetry Pcnn, and at $\sim 1020^{\circ} \mathrm{C}, \alpha-\mathrm{BiNbO}_{4}$ undergoes an irreversible phase-transition to the triclinic $\beta$-form (Keve \& Skapski 1973, Roth \& Waring 1963). Ponomarev et al. (1981) showed that the structure of $\mathrm{SbNbO}_{4}$ is polar $\left(P c 2_{1} n\right)$ at low temperature and is centrosymmetric (Pcnn) above 
$683 \mathrm{~K}$; this phase transition is reversible. A structure is reported for stibiotantalite, $\mathrm{SbTaO}_{4}$, with the polar space-group $P c 2_{1} n$ (Dihlström 1938).

To summarize, at low temperature, the solid-solution series between $\mathrm{BiTaO}_{4}$ and $\mathrm{BiNbO}_{4}$ has Pcnn symmetry, and the solid-solution series between $\mathrm{SbTaO}_{4}$ and $\mathrm{SbNbO}_{4}$ has $\mathrm{Pc}_{1} n$ symmetry. Thus a particular $\mathrm{Sb} /(\mathrm{Sb}$ $+\mathrm{Bi}$ ) ratio [for a specific $\mathrm{Nb} /(\mathrm{Nb}+\mathrm{Ta})$ ratio] must mark the compositional boundary at which the centrosymmetric Pcnn structure transforms to the polar $P c 2_{1} n$ structure. Our results show that up to $\sim 40 \%$ replacement of $\mathrm{Bi}^{3+}$ by $\mathrm{Sb}^{3+}$ (Table 4) can be accommodated within the Pcnn structure. A related study reported the existence of two solid-solutions for $\mathrm{Bi}_{2-x} \mathrm{Sb}_{x} \mathrm{WO}_{6}$ (Castro et al. 1995). For compositions with $0 \leq x \leq 1.25$, an orthorhombic phase forms; at high Sb content $(1.5 \leq x \leq 2)$, a triclinic phase forms. The authors attributed the compositionally driven phase-transition to the different stereochemical activities of the lone pairs of electrons associated with $\mathrm{Bi}^{3+}$ and $\mathrm{Sb}^{3+}$ (Galy et al. 1975). Although the structures of $\mathrm{Bi}_{2-x} \mathrm{Sb}_{x} \mathrm{WO}_{6}$ and $(\mathrm{Bi}, \mathrm{Sb})$ $(\mathrm{Ta}, \mathrm{Nb}) \mathrm{O}_{4}$ differ, it would be interesting to compare the critical $75 \% \mathrm{Sb}$ content required in the former, with that needed in the latter, to induce structural transition. In practice, one could follow the structural change $\left(P c 2{ }_{1} n\right.$ to $P(n n)$ as a function of both composition and temperature within the $(\mathrm{Bi}, \mathrm{Sb})(\mathrm{Ta}, \mathrm{Nb}) \mathrm{O}_{4}$ system.

\section{ACKNOWLEDGEMENTS}

We thank Carlo Maria Gramaccioli, an anonymous reviewer, Associate Editor Giancarlo Della Ventura and the green-ink man, Bob Martin, for their comments on this paper. M.A.G. is very grateful to the late Bernardo Shain for donation of the bismutotantalite samples, to the Fundación Antorchas for financing a stay at the University of Manitoba, and to CONICET for the grant supporting the project PIP 319. NSERC Major Installation and Research Grants to P.C.., and Major Equipment Research and Major Facilities Access Grants to F.C.H. financed work at the University of Manitoba.

\section{REFERENCES}

AhlFeld, F. \& ANGelelli, V. (1948): Las especies minerales de la República Argentina. Instituto de Geología y Minería (Jujuy), Universidad Nacional de Tucumán, Publ. 458.

ApPleman, D.E. \& Evans, H.T., JR. (1973): Job 9214: indexing and least-squares refinement of powder diffraction data. U.S. Geol. Surv., Computer Contrib. 20 (NTIS Doc. PB216188).

Bhaskara RaO, A. \& Adusumilli, M.S. (1966): Bismuth minerals from Borborema region, Brazil. Mineral. Mag. 35, 785-787.
Castro, A., Millan, P. \& Enjalbert, R. (1995): Structural evolution of the Aurivillius framework in the solid solutions $\mathrm{Bi}_{2} \mathrm{WO}_{6}-\mathrm{Sb}_{2} \mathrm{WO}_{6}$. Mater. Res. Bull. 30, 871-882.

ČERnY, P. \& ERCIT, T.S. (1989): Mineralogy of niobium and tantalum: crystal chemical relationships, paragenetic aspects and their economic implications. In Lanthanides, Tantalum and Niobium (P. Møller, P. Černý \& F. Saupé, eds.). Springer-Verlag, Heidelberg, Germany (27-79).

Correia Neves, J.M., Lopes Nunes, J.E., Sahama, T.G., LEHTINEN, M. \& VON KNORRING, O. (1974): Bismuth and antimony minerals in the granite pegmatites of northern Mozambique. Revista de Ciencias Geologicas, Universidade de Lourenço Marques, Ser. A 7, 1-37.

DinlströM, K. (1938): Über den Bau des wahren Antimontetroxyds und des damit isomorphen Stibiotantalits, $\mathrm{SbTaO}_{4}$. Z. Anorg. Chem. 239, 57-64.

FooRD, E.E. (1982): Minerals of tin, titanium, niobium and tantalum in granitic pegmatites. In Granitic Pegmatites in Science and Industry (P. Černý, ed.). Mineral. Assoc. Can., Short-Course Handbook 8, 187-238.

Frenzel, G. (1955): Zur Kenntnis von Bismutotantalit. Neues Jahrb. Mineral., Monatsh., 241-250.

GALliski, M.A. (1983a): Distrito minero El Quemado, Deptos. La Poma y Cachi, provincia de Salta. I. El basamento del tramo septentrional de la sierra de Cachi. Revista de la Asociación Geológica Argentina 38, 209-224.

(1983b): Distrito minero El Quemado, Deptos. La Poma y Cachi, provincia de Salta. II. Geología de sus pegmatitas. Revista de la Asociación Geológica Argentina 38, 340-380.

Galy, J., Meunier, G., Andersson, S. \& Åström, A. (1975): Stéréochimie des éléments comportant des paires non liées: Ge(II), As(III), Se(IV), Br(V), Sn(II), Sb(III), Te(IV), I(V), $\mathrm{Xe}(\mathrm{VI}), \mathrm{Tl}(\mathrm{I}), \mathrm{Pb}(\mathrm{II})$, et $\mathrm{Bi}(\mathrm{III})$ (oxydes, fluorures et oxyfluorures). J. Solid State Chem. 13, 142-159.

HuRLbut, C.S., JR. (1957): Bismutotantalite from Brazil. Am. Mineral. 42, 178-183.

Keve, E.T. \& SkAPSKI, A.C. (1973): The crystal structure of triclinic $\beta-\mathrm{BiNbO}_{4}$. J. Solid State Chem. 8, 159-165.

Pauly, H. (1986): Effects of different polishing methods on the reflectance of silicon. Tschermaks Mineral. Petrogr. Mitt. 35, 261-273.

PENFIELD, S.L. \& Ford, W.E. (1906): On stibiotantalite. Am. J. Sci. 172, 61-77.

Ponomarev, V.I., FiliPenKo, O.S., Atovmyan, L.O., RANNEv, N.V., Ivanov, S.A. \& Venevtsev, Yu.N. (1981): Structure and lattice dynamics of $\mathrm{SbNbO}_{4}$ crystals at 300$1000^{\circ}$ K. Kristallografiya 26, 341-348. 
Pouchou, J.-L. \& Pichoir, F. (1984): A new model for quantitative analysis. 1. Application to the analysis of homogeneous samples. Recherche Aérosp. 5, 47-65.

$\&$ (1985): "PAP" $(\phi \rho Z)$ correction procedure for improved quantitative microanalysis. In Microbeam Analysis (J. T. Armstrong, ed.), San Francisco Press, San Francisco, California (104-106).

Roth, R.S. \& WARING J.L. (1963): Synthesis and stability of bismutotantalite, stibiotantalite and chemically similar $\mathrm{ABO}_{4}$ compounds. Am. Mineral. 48, 1348-1356.

Subramanian, M.A. \& CAlabrese J.C. (1993): Crystal structure of the low temperature form of bismuth niobium oxide [ $\alpha$-BiNbO4]. Mater. Res. Bull. 28, 523-529.
Voloshin, A.V., Pakhomovskyi, Ya.A., Stepanov, V.I. \& Tyusheva, F.N. (1983): Natrobistantite, (Na,Cs)Bi $(\mathrm{Ta}, \mathrm{Nb}, \mathrm{Sb})_{4} \mathrm{O}_{12}-$ a new mineral from granitic pegmatites. Mineral. Zh. 5(2), 82-86 (in Russ.).

VON KNORRING O. \& FADIPE, A. (1981): On the mineralogy and geochemistry of niobium and tantalum in some granite pegmatites and alkali granites of Africa. Bull. Minéral. 104, 496-507.

WAYland, E.J. \& SPENCER, L.J. (1929): Bismutotantalite, a new mineral, from Uganda. Mineral. Mag. 22, 185-192.

Received May 29, 2000, revised manuscript accepted January 3, 2001. 